\title{
THE STATISTICAL ANALYSIS OF LABOR MARKET AND FEMALE LABOR FORCE CHARACTERISTICS IN CENTRAL AND EASTERN EUROPEAN COUNTRIES
}

\author{
Elisabeta Jaba \\ Department of Accounting, Business Information Systems and Statistics, Faculty of Economics \\ and Business Administration, Alexandru Ioan Cuza University of Iași, Romania \\ ejaba@uaic.ro \\ Christiana Brigitte Sandu \\ Department of Accounting, Business Information Systems and Statistics, Faculty of Economics \\ and Business Administration, Alexandru Ioan Cuza University of Iași, Romania \\ christiana.balan@uaic.ro \\ Aurelian-Petruș Plopeanu \\ Alexandru Ioan Cuza University of Iași, Department of Interdisciplinary Research - \\ Humanities and Social Sciences, Romania \\ aplopeanu@gmail.com \\ Ioan-Bogdan Robu \\ Department of Economics, Faculty of Economics and Business Administration, Alexandru Ioan \\ Cuza University of Iași, Romania \\ bogdan.robu@feaa.uaic.ro \\ Marinela Istrate \\ Department of Geography, Faculty of Geography and Geology, Alexandru Ioan Cuza \\ University of Iași, Romania
}

\begin{abstract}
In this paper we analyze the characteristics of labor markets and female labor force in the countries from Central and Eastern Europe in order to verify the existence of significant differences in female labor participation rate among the countries that experienced the same political and economic system before 1990. The paper seeks to address the following specific objectives: 1) to identify the variables which are strongly correlated with female labor force participation, objective met using correlation analysis; 2) to define clusters of countries based on the determinants of female participation on the labor market, identified previously, using hierarchical cluster method; 3) to verify if the female labor force participation rate differs significantly among the identified clusters by applying the analysis of variance. The results of this study highlight that, in Central and Eastern Europe, we can identify four clusters of countries that share common characteristics of female labor market and female labor force. The analysis of the variation in female labor force participation rate emphasizes different patterns according to identified groups of countries.
\end{abstract}

\section{Keywords}

female employment; labor market; education; religion; hierarchical cluster analysis

\section{JEL Classification}

C38; E23; I23; Z12

\section{Introduction}

We aim to assess female labor force characteristics in relation to labor market characteristics for Central and Eastern European countries. These countries experienced, in the second half of the 20th century, similar political and social regimes 
defined by planned economies that played an important role in shaping the female employment and influenced the characteristics of female labor force. The high participation rate of women on the labor market in these countries mirrors the twobread winner family scheme that was promoted by the socialist policies (Pastore and Verashchagina, 2008; Jaba, 1979). This pattern evolved differently during the transition to the market economy with defining clusters of countries according to female labor market and female labor force characteristics. The process of privatization of stateowned enterprises and the process of liberalization of wage setting mechanisms implied hard budget constraints for companies in Central and Eastern European countries with negative consequences on women employment (Paci and Reilly, 2004; Pastore and Verashchagina, 2008).

Nowadays, in Europe, the female participation on the labor market is smaller than male participation, and in addition, there are significant differences among countries. Recent studies (OECD, 2009; Diaz Garcia and Welter, 2011) have shown the persistent gender gap in employment in the European countries. In many Northern European countries, the female activity rate is high, while the female unemployment rate is low (European Commission, 2011). On the contrary, in many Southern and Eastern European countries, the female activity rates are very low, while the female unemployment is very high, in comparison to the average level for the European Union. However, the female labor force participation has grown substantially in the last decades (GutierrezDomenech and Bell, 2004; DiCecio, Engemann, Owyang and Wheeler, 2008; Cloin, Keuzenkamp and Plantenga, 2011). In the Netherlands, United Kingdom, Denmark and Germany there was an important increase in female labor market participation, but there are important differences under the influence of various factors (Noback, Broersma and Van Dijk, 2013). The gender gap in employment is explained either by the labor force characteristics such as education or by labor market characteristics particular to each country such as the level of development, the revenue and the unemployment rate. For 15 European Union countries over the last 20 years, Cipollone, Patacchini and Vallanti (2013) found that female labor market participation is influenced, firstly, by the differences in the labor market institutional settings and, secondly, in social policy. Also, for the transition countries, tax rates, tax administration, and policy uncertainty, as well as corruption, play an important role in explaining the results on the labor market (Cazes, 2002).

Furthermore, religion is considered to be a causal factor in explaining many crosscountry differences in female participation on the labor market (Norton and Tomal, 2009; Pastore and Tenaglia, 2013). Nowadays, the emergent economies in Europe experience both political and religious diversity with important effects over the individuals and society (Brăilean, 2014). Commenting on the complex influence of the religious ideas on the human action, Inglehart and Baker (2000: 49) consider that "the fact that a society was historically shaped by Protestantism or Confucianism or Islam leaves a cultural heritage with enduring effects that influence subsequent developments". Religion can explain more than one-third of the cross-country variation in female labor force participation rates (Norton and Tomal, 2009).

The present paper focuses on identifying the female labor force and labor market characteristics that are common to Central and Eastern European countries in order to highlight the existence of similarities among them. There are three main objectives subordinated to the aim of the paper: 1) to identify the variables that are correlated to female labor force participation; 2) to define clusters of homogenous countries according to female labor force and labor market characteristics; 3) to verify the existence of significant differences among clusters of countries defined according to female labor force participation.

The results of the study show that Central and Eastern European countries vary according to the characteristics of labor market and female labor force. Based on these 
variables the observed countries have been classified in four clusters that show different patterns regarding the female labor force participation.

The remaining part of the paper proceeds as follows: Section Data and Method presents the sample of countries used in the analysis as well as the definition of the labor market indicators. This section also describes the statistical methods applied with the aim of accomplishing the objectives set for this study; Section Results presents the main findings related to the clusters of countries that share common characteristics of female labor market and female labor force. The differences among clusters of countries regarding female labor force participation rate are also explained by the religious affiliation of the population; Conclusion section give a brief summary of the findings and discuss the implications for labor markets' policies in the region.

\section{Data and Method}

\section{Data}

For 15 Central and Eastern European countries (Bulgaria, Croatia, Czech Republic, Estonia, Hungary, Latvia, Lithuania, Macedonia, Montenegro, Poland, Romania, Russia, Serbia, Slovak Republic, and Slovenia), we have recorded a series of macroeconomic indicators, which characterize both the labor market and the female labor force. These variables which refer to the main characteristics of the labor markets and female participation on the labor market are presented in Table 1.

Data on these variables have been gathered from various sources, mainly from the World Bank, IMF, and OECD databases, for year 2012. Data on labor market and business regulations index have been collected from the Economic Freedom of the World: 2014 Annual Report published by Fraser Institute.

Data management and analysis were performed using SPSS 21.0.

Table 1 Variables describing labor market and female labor force characteristics

\begin{tabular}{|c|c|c|c|}
\hline Variables & Explanation & Variables & Explanation \\
\hline $\begin{array}{l}X_{1}-\text { Labor } \\
\text { mar } \\
\text { ket } \\
\text { regulation } \\
\mathrm{s} \text { index }\end{array}$ & $\begin{array}{l}\text { Sub-index of the } \\
\text { Economic Freedom of } \\
\text { the World (EFW). The } \\
\text { rating scale ranges from } 0 \\
\text { to } 10 \text { (higher values } \\
\text { represent more flexible } \\
\text { regulation) }\end{array}$ & $\begin{array}{l}\mathrm{X}_{9}-\text { Prevalence of } \\
\text { foreign ownership }\end{array}$ & $\begin{array}{l}\text { The rating scale } \\
\text { ranges from } 1 \text { to } 7(1 \\
\text { - very rare; } 7- \\
\text { highly prevalent) }\end{array}$ \\
\hline $\begin{array}{l}\mathrm{X}_{2-} \\
\text { Business } \\
\text { regulation } \\
\mathrm{s} \text { index }\end{array}$ & $\begin{array}{l}\text { Sub-index of the } \\
\text { Economic Freedom of } \\
\text { the World (EFW). The } \\
\text { rating scale ranges from } 0 \\
\text { to } 10 \text { (higher values } \\
\text { represent more flexible } \\
\text { regulation) }\end{array}$ & $\begin{array}{l}\mathrm{X}_{10}-\text { Domestic } \\
\text { market size index }\end{array}$ & $\begin{array}{l}\text { Sum of gross } \\
\text { domestic product } \\
\text { plus value of imports } \\
\text { of goods and } \\
\text { services, minus } \\
\text { value of exports of } \\
\text { goods and services, } \\
\text { normalized on a } \\
\text { 1(poor) }-7 \text { (best) } \\
\text { scale }\end{array}$ \\
\hline $\begin{array}{l}\mathrm{X}_{3}-\text { Labor } \\
\text { market } \\
\text { efficiency }\end{array}$ & $\begin{array}{l}\text { The rating scale ranges } \\
\text { from } 1 \text { to } 7 \text { (higher values } \\
\text { represent more efficient } \\
\text { labor market) }\end{array}$ & $\begin{array}{l}\mathrm{X}_{11}-\text { Flexibility of } \\
\text { wage } \\
\text { determination }\end{array}$ & $\begin{array}{l}\text { The rating scale } \\
\text { ranges from } 1 \text { to } 7(1 \\
- \text { by a centralized } \\
\text { bargaining process; }\end{array}$ \\
\hline
\end{tabular}




\begin{tabular}{|c|c|c|c|}
\hline & & & $\begin{array}{l}7-\text { up to each } \\
\text { individual company) }\end{array}$ \\
\hline $\begin{array}{l}\mathrm{X}_{4}-\text { Trade } \\
\text { union } \\
\text { density }\end{array}$ & $\begin{array}{l}\text { Share of employees in } \\
\text { trade unions }(\%)\end{array}$ & $\begin{array}{l}\mathrm{X}_{12}-\text { Firms with } \\
\text { female } \\
\text { participation } \\
\text { ownership }(\%)\end{array}$ & $\begin{array}{l}\text { The percentage of } \\
\text { firms with a woman } \\
\text { among the principal } \\
\text { owners }(\%)\end{array}$ \\
\hline $\begin{array}{l}\mathrm{X}_{5}-\mathrm{GDP} \\
\text { per capita }\end{array}$ & $\begin{array}{l}\text { GDP per capita expressed } \\
\text { in current US dollars }\end{array}$ & $\begin{array}{l}\mathrm{X}_{13}-\text { Female } \\
\text { tertiary education } \\
\text { enrollment }(\%)\end{array}$ & $\begin{array}{l}\text { Percentage of } \\
\text { students enrolled in } \\
\text { tertiary education } \\
\text { who are female , } \\
\text { regardless of age, as } \\
\text { a share of the } \\
\text { population of the age } \\
\text { group that officially } \\
\text { corresponds to this } \\
\text { level of education }\end{array}$ \\
\hline $\begin{array}{l}\mathrm{X}_{6-} \\
\text { Intensity } \\
\text { of local } \\
\text { competitio } \\
\mathrm{n}\end{array}$ & $\begin{array}{l}\text { The rating scale ranges } \\
\text { from } 1 \text { to } 7 \text { ( } 1 \text { - limited } \\
\text { competition in most } \\
\text { industries; } 7-\text { intense } \\
\text { competition in most } \\
\text { industries) }\end{array}$ & $\begin{array}{l}\mathrm{X}_{14-\text { Share }} \text { of } \\
\text { women employed } \\
\text { in the non- } \\
\text { agricultural sector } \\
(\%)\end{array}$ & $\begin{array}{l}\text { The share of female } \\
\text { workers in the non- } \\
\text { agricultural sector } \\
\text { (industry and } \\
\text { services), expressed } \\
\text { as a percentage of } \\
\text { total employment in } \\
\text { the non-agricultural } \\
\text { sector }\end{array}$ \\
\hline $\begin{array}{l}\mathrm{X}_{7}-\text { Extent } \\
\text { of market } \\
\text { dominanc } \\
\mathrm{e}\end{array}$ & $\begin{array}{l}\text { The characterization of } \\
\text { corporate activity on a } \\
\text { scale from } 1 \text { to } 7 \text { ( } 1- \\
\text { dominated by a few } \\
\text { business groups; } 7- \\
\text { spread among many } \\
\text { firms) }\end{array}$ & $\begin{array}{l}\mathrm{X}_{15}-\text { Female labor } \\
\text { force participation } \\
\text { rate }(\%)\end{array}$ & $\begin{array}{l}\text { The proportion of } \\
\text { the female } \\
\text { population ages } 15 \\
\text { and older that is } \\
\text { economically active. } \\
\text { Female labor force } \\
\text { participation } \\
\text { consists in all female } \\
\text { supply labor used for } \\
\text { the production of } \\
\text { goods and services } \\
\text { during a specified } \\
\text { period of time. }\end{array}$ \\
\hline $\begin{array}{l}\mathrm{X}_{8}-\text { Total } \\
\text { tax rate }\end{array}$ & $\begin{array}{l}\text { A combination of profit } \\
\text { tax ( } \% \text { of profits), labor } \\
\text { tax and contribution ( } \% \\
\text { of profits), and other } \\
\text { taxes ( } \% \text { of profits) }\end{array}$ & $\begin{array}{l}X_{16}-X_{19}-\text { Share of } \\
\text { persons of } a \\
\text { specific religion } \\
(\%)\end{array}$ & $\begin{array}{l}\text { The share of } \\
\text { Christians / Muslims } \\
\text { / Agnostics / } \\
\text { Atheists in the total } \\
\text { population of each } \\
\text { country }\end{array}$ \\
\hline
\end{tabular}

Source: World Bank; IMF; OECD; Fraser Institute

\section{Methods}

We propose a methodological approach to identify the differences in female labor force participation rate among the clusters of similar countries according to a set of variables regarding female labor force and labor market characteristics. It consists in the following phases:

1) In the first phase, we identify the variables that are correlated with female labor force participation, using the correlation analysis, namely Pearson 
correlation coefficient. From the initial set of variables, we have selected those variables that have a strong correlation with female labor force participation. These variables are considered for the identification of clusters of countries and, therefore, for the explanation of the differences and the similarities among countries from Central and Eastern Europe.

2) Considering the labor market and female labor force characteristics, identified previously through the correlation analysis, we cluster the observed European countries into subgroups that have similar patterns.

In the literature, there are various algorithms used for data clustering, such as: hierarchical cluster analysis, k-means cluster, and two-step cluster (Norusis, 2011). The clustering methods are divided into hard methods (data subsets are mutually exclusive) and fuzzy methods (units are allowed to belong to several clusters simultaneously, with different degrees of membership) (Cattinelli, Valentini, Paulesu and Borghese, 2013; Palașcă, Enea, Jaba and Roman, 2014).

In this study, we apply a hard method, using the agglomerative hierarchical clustering technique. It starts with the countries as individual clusters, and at each step, it merges the closest pair of clusters until only one cluster left. Clusters are defined using the squared Euclidean distance, which is the sum of the squared differences over all of the variables $\left(X_{1}, X_{2}, \ldots, X_{p}\right)$. The formula of the distance between two entities (countries) $i$ and $j$ is the following:

$$
D_{i j}^{2}=\left(x_{1 i}-x_{1 j}\right)^{2}+\left(x_{2 i}-x_{2 j}\right)^{2}+\ldots+\left(x_{p i}-x_{p j}\right)^{2}
$$

where

- $\quad D_{i j}$ is the distance between two countries, $i$ and $j$.

- $x_{1 i}, x_{2 i}, \ldots, x_{p i}$ are the observed data for country $i$ on the $X_{1}, X_{2}, \ldots, X_{p}$ variables;

- $x_{1 j}, x_{2 j}, \ldots, x_{p j}$ are the observed data for country $j$ on the same set of variables;

The distance $D_{i j}$ depends on the units in which the variables $X_{1}, X_{2}, \ldots, X_{p}$ are measured and is influenced by whichever variable takes numerically larger values. Therefore, before applying cluster analysis, the variables are standardized, so that they have mean 0 and variance 1 (Tryfos, 1998).

The visual representation of the distance at which clusters are combined is displayed through the dendrogram (Tan, Steinbach and Kumar, 2006). The vertical lines of this diagram show joined clusters and the distance at which these clusters are merged.

3) We identify significant differences according to female labor force participation among the identified clusters of countries using the ANOVA method (the analysis of variance).

This method allows comparing the clusters' means, based on independent random samples. We test the null hypothesis that $k$ populations' means are all equal against the alternative hypothesis that at least two means differ:

$$
\begin{aligned}
& H_{0}: \mu_{1}=\mu_{2}=\ldots=\mu_{k} \\
& H_{1}: \text { at least two of the group means are not equal }
\end{aligned}
$$

The ANOVA method allows quantifying two types of variation: the within groups' variability, by the sum of squares of the differences between each value and its group mean $\left(S S_{\text {within }}\right)$; and between groups' variation, by the sum of the squares of the differences between the groups' means and the overall sample mean $\left(S S_{\text {between }}\right)$.

In order to test if the difference between the means is attributable to sampling error (the means are approximately equal) or the population means differ, the Fisher statistic is used. The F statistic is the ratio of the mean squares of the differences. 


$$
F=\frac{M S_{\text {between }}}{M S_{\text {within }}}=\frac{S S_{\text {between }} / d f_{\text {between }}}{S S_{\text {within }} / d f_{\text {within }}}=\frac{S S_{\text {between }} /(\mathrm{k}-1)}{S S_{\text {within }} /(\mathrm{n}-\mathrm{k})}
$$

where:

- $M S_{\text {between }}$ is the variance estimate explained by the different groups;

- $M S_{\text {within }}$ is the variance estimate due to chance (unexplained);

- $d f_{\text {between }}$ are the degrees of freedom for $k$ groups;

- $d f_{\text {within }}$ are the degrees of freedom for errors within groups.

The test of the difference between the means of any pair of populations is conducted using the multiple comparisons tests, namely Student-Newman-Keuls test for pairwise comparisons. When there are three means, this test holds the familywise error rate at 0.05 . The test of the difference between the means of two groups, $e$ and $f$, is the following:

$$
q=\frac{\bar{x}_{e}-\bar{x}_{f}}{\sqrt{\frac{M S_{\text {error }}}{n}}}
$$

The variation within each cluster of countries is graphically presented using the boxplots. The box-plot diagram shows the range of values of a variable, the range between the middle $50 \%$ of the values fall, the median value and it shows whether a distribution is symmetrical or skewed.

The most important results of the statistical methods applied in SPSS are presented in the following section.

\section{Results and Discussions \\ Correlations between female labor force participation and the characteristics of female labor force and labor market}

The analysis starts with a first set of variables proposed by the literature for the description of the characteristics of both labor market and female labor force (see Table 1). From the initial set of variables we kept only the variables that are correlated significantly with the female labor force participation rate. In 2012, the Eastern European countries are diverse with respect to female labor force participation. It varies among the 15 countries, as it is the highest in Russia (57\%) and in the Baltic Countries (55\% and 56\%), and has the lowest values in Macedonia and Montenegro (43\%) and in Serbia (44\%). Compared to the Eastern Europe countries, it can be seen that, in Europe, Northern European countries have higher values (Norway - 62\%, Sweden $60 \%$, and Denmark - 59\%), and, in the world, China has even more important female participation rate $(64 \%)$. In United States of America, the female labor force participation is $57 \%$.

There are six variables that are correlated with female labor force participation rate, and all correlations have positive signs. The first two variables are related to female labor force characteristics and the last four variables are related to the labor market characteristics. These variables are:

- $\quad$ Share of women employed in the non-agricultural sector $(r=0.792$ with a p-value smaller than 1\%). It is considered that female labor-force participation in nonagricultural sector in the developing countries is a key factor for the structural adjustment and to the international competitiveness (Karshenas, 1997). Moreover, Heinegg, Melzig and Sprout (2007) underline that in the transition countries, the female labor force in services are in as high as in the developed economies. As regarding the share of women employed in the non-agricultural sector in Central and Eastern Europe, Macedonia has the smallest percentage (42\%), while the Baltic countries have the maximum values (54\% in Latvia and Lithuania). 
- Female tertiary education enrolment ( $r=0.731$ with a $p$-value smaller than $1 \%)$. There are many studies that emphasize the impact of female education on the structure of labor market. According to McDaniel (2014), if females continue to outpace men in tertiary enrolment, the effect would be a general decrease of gender gaps in the level of wages and an increase participation in the labor market. However, Aboohamidi and Chimdi (2013) found out that in Egypt, Morocco, Turkey and Pakistan, female tertiary education had a negative effect on female labor participation rate due to activities that did not require complicated knowledge and skills. There is important variation among the observed countries according to female school enrolment in tertiary education. Slovenia has the highest percentage of female tertiary education enrollment, comparable to the levels of USA or Finland; while in Macedonia and Romania this indicator show the lowest values among the 15 Eastern European countries.

- Gross domestic product per capita $(r=0.690$ correlation with a $p$-value smaller than $1 \%$ ), measures the total value per capita, in market prices, for the goods and services produced within a country during one year by the national economic and non-residents under alternative exchange rate between the currencies of two countries. Several studies demonstrated the macroeconomic impact of the gender divided labor market. It has conclusively been shown that a country may benefit by the fully insertion of women in the labor market (Dollar and Gatti, 1999). While Cuberes and Teignier (2012) demonstrated that gender gaps in the labor market may generate GDP per capita losses up to $27 \%$ in some regions, other researchers, however, stressed that, in the case of several countries like United States of America, Japan, United Arab Emirates, and Egypt, raising the female labor force participation rate to male levels could raise the level of GDP (DeAnne, Hoteit, Rupp, Sabbagh, 2012). Other studies highlighted that female labor force participation rate varies pointing to a U-shaped relationship with per capita income (Elborgh-Woytek, Newiak, Kochhar, Fabrizio, Kpodar, Wingender, Clements, Schwartz, 2013). Nevertheless, Aboohamidi and Chimdi (2013) noted that in Egypt, Morocco, Turkey and Pakistan, when GDP per capita raised, the female labor force participation rate declined. GDP per capita in Central and Eastern European countries is below the level reached by the developed countries in Europe. Among the 15 observed countries, Slovenia is the country with the highest levels of GDP per capita (22,756 USD per capita). However, at European level, GDP per capita is more important, reaching 60,000 USD per capita in Denmark.

- Total tax rate $(r=0.620$ with a $p$-value smaller than $5 \%)$. The tax system influences the work incentives and the female participation by affecting differently married and single women (Jaumotte, 2003).

- $\quad$ Labor market efficiency $(r=0.584$ with a $p$-value smaller than $5 \%)$. It is considered that low female employment rate has a negative effect on labor market efficiency because important human capital is diminished and, consequently, low levels of incomes are generated (Anker, 1998).

- Intensity of local competition ( $r=0.533$ with a $p$-value smaller than 5\%). Global and local competition is an important factor of employment rate as it has impact on the quality of working life (Wilton, 2013). The increasing competition on the labor market, especially for flexible work opportunities in the private sector, requires government strategies for growth in order to reach more women (Sands, 2013).

The variables defining the structure of the population by religion are poorly correlated with female labor force participation rate. However, the sign of the correlations differs for the four religions considered in the study: the share of Christian population and the share of Muslim population are both negatively correlated with 
female labor force participation, while the other two religions show a positive effect on the female participation in the labor market. The correlations are:

- Share of Christian population ( $r=-0.030$ with a $p$-value higher than $10 \%)$. Other studies validated that Christian Orthodox and Muslim women presented a higher risk of non-employment than the agnostics and, in a much greater degree, a probability of employment of $30 \%$ to $40 \%$ lower than the average level.

- Share of Muslim population $(r=-0.481$ with a $p$-value lower than $10 \%)$. In a crosssection of countries in the period 1985 - 2005, [12] found that female labor force participation varies depending on the religion practice: it is lower in Muslim countries and higher in the Protestant ones or where no religion is practiced.

- $\quad$ Share of Agnostic population ( $r=0.367$ with a $p$-value higher than $10 \%)$.

- $\quad$ Share of Atheist population ( $r=0.233$ with a $p$-value higher than $10 \%)$.

\section{Clusters of countries according to the characteristics of labor market and female labor force}

Since some countries have similar patterns to other countries on some of the characteristics regarding female labor force and labor market, and different patterns on other characteristics, we aim to identify similarities in our data. Therefore, we apply the cluster analysis on ten variables identified at the previous step, including four other variables regarding the structure of the population by religion.

Based on the distance between the pairs of clusters merged at each step, we obtained four groups of countries, as shown in the dendrogram below (Figure 1).

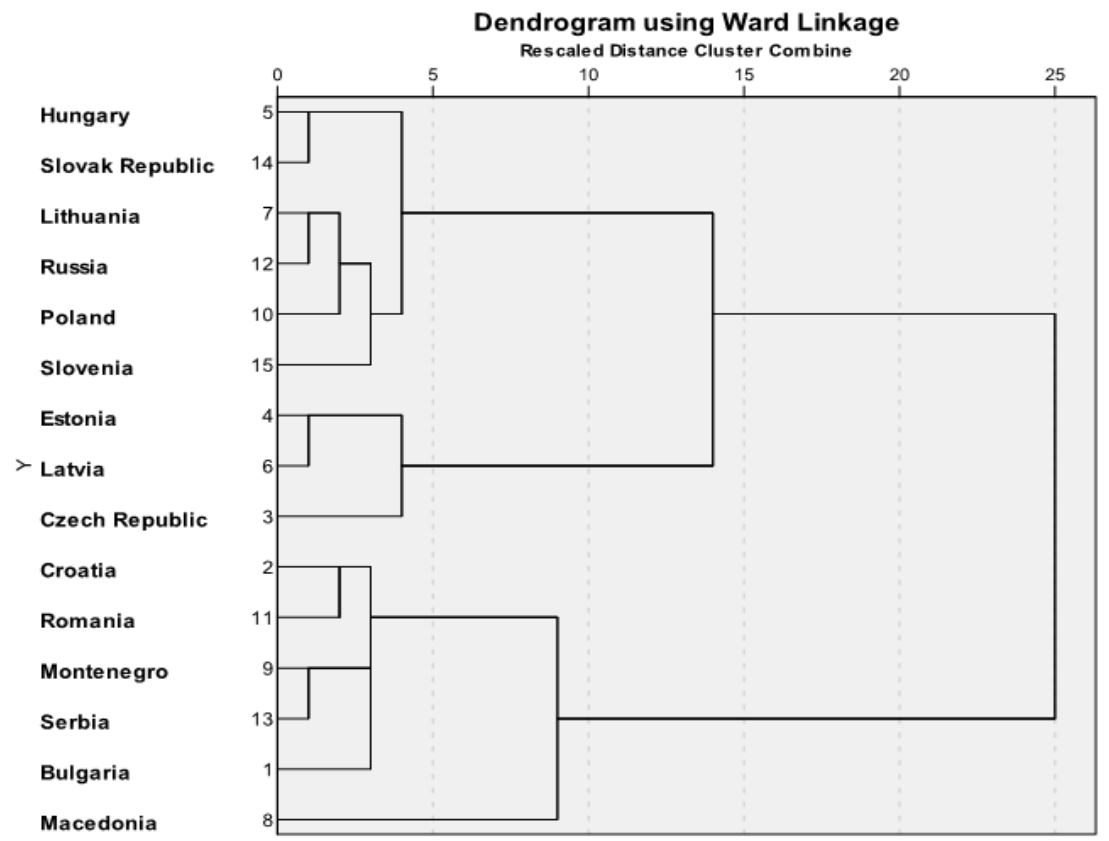

Figure 1 Clusters of countries according to determinant factors Source: Authors' tabulation in SPSS 20.0

The solution with four clusters underlines the following groups of countries:

Cluster 1 (5 countries): Bulgaria, Croatia, Montenegro, Romania, and Serbia; 
THE STATISTICAL ANALYSIS OF LABOR MARKET AND FEMALE LABOR FORCE CHARACTERISTICS IN CENTRAL AND EASTERN EUROPEAN COUNTRIES

- Cluster 2 (3 countries): Czech Republic, Estonia, and Latvia;

- Cluster 3 (6 countries): Hungary, Lithuania, Poland, Russia, Slovakia, and Slovenia;

- Cluster 4 ( 1 country): Macedonia.

The profile of the four clusters is derived using the descriptive statistics of the variables on female labor force and labor market characteristics, by clusters (Table 2).

Table 2 The clusters' profile according to the labor market and female labor force characteristics

\begin{tabular}{|c|c|c|c|c|c|}
\hline & Cluster & Mean & Std. Deviation & Min. & Max. \\
\hline \multirow{4}{*}{$\begin{array}{ll}\text { Labor } & \text { Market } \\
\text { Efficiency } & \end{array}$} & 1 & 4.14 & 0.227 & 4.00 & 4.54 \\
\hline & 2 & 4.73 & 0.396 & 4.32 & 5.11 \\
\hline & 3 & 4.29 & 0.128 & 4.15 & 4.48 \\
\hline & 4 & 4.13 & - & 4.13 & 4.13 \\
\hline \multirow{4}{*}{$\begin{array}{l}\text { GDP per capita (current } \\
\text { US dollars) }\end{array}$} & 1 & 8546.60 & 3002.124 & 5907.00 & 13562.00 \\
\hline & 2 & 17698.33 & 2161.041 & 15205.00 & 19032.00 \\
\hline & 3 & 16347.16 & 3542.622 & 13394.00 & 22756.00 \\
\hline & 4 & 4944.00 & - & 4944.00 & 4944.00 \\
\hline \multirow{4}{*}{$\begin{array}{lr}\text { Female } & \text { tertiary } \\
\text { education } & \text { enrollment } \\
\text { rate } & \end{array}$} & 1 & 56.76 & 5.146 & 51.60 & 62.70 \\
\hline & 2 & 68.66 & 6.971 & 64.20 & 76.70 \\
\hline & 3 & 70.65 & 11.369 & 55.10 & 86.00 \\
\hline & 4 & 38.50 & - & 38.50 & 38.50 \\
\hline \multirow{4}{*}{$\begin{array}{l}\text { Intensity of local } \\
\text { competition }\end{array}$} & 1 & 4.48 & 0.465 & 3.90 & 5.00 \\
\hline & 2 & 5.60 & 0.100 & 5.50 & 5.70 \\
\hline & 3 & 5.30 & 0.228 & 5.00 & 5.60 \\
\hline & 4 & 5.40 & - & 5.40 & 5.40 \\
\hline \multirow[t]{4}{*}{ Total tax rate } & 1 & 29.62 & 10.050 & 19.80 & 42.90 \\
\hline & 2 & 44.46 & 7.447 & 35.90 & 49.40 \\
\hline & 3 & 44.13 & 6.728 & 32.50 & 50.70 \\
\hline & 4 & 8.20 & - & 8.20 & 8.20 \\
\hline \multirow{4}{*}{$\begin{array}{l}\text { Share of women } \\
\text { employed in } \\
\text { nonagricultural sector }\end{array}$} & 1 & 47.00 & 1.870 & 45.00 & 50.00 \\
\hline & 2 & 51.00 & 4.358 & 46.00 & 54.00 \\
\hline & 3 & 49.50 & 2.588 & 47.00 & 54.00 \\
\hline & 4 & 42.00 & - & 42.00 & 42.00 \\
\hline \multirow[t]{4}{*}{ Christians (\%) } & 1 & 86.35 & 8.502 & 77.67 & 98.49 \\
\hline & 2 & 65.23 & 8.111 & 55.93 & 70.84 \\
\hline & 3 & 88.05 & 4.973 & 81.25 & 96.15 \\
\hline & 4 & 64.56 & - & 64.56 & 64.56 \\
\hline \multirow[t]{4}{*}{ Muslims (\%) } & 1 & 7.65 & 6.685 & 0.42 & 16.45 \\
\hline & 2 & 0.18 & 0.147 & 0.01 & 0.28 \\
\hline & 3 & 2.22 & 4.103 & 0.01 & 10.39 \\
\hline & 4 & 28.97 & - & 28.97 & 28.97 \\
\hline \multirow[t]{4}{*}{ Agnostics (\%) } & 1 & 4.70 & 3.238 & 0.88 & 9.66 \\
\hline & 2 & 29.27 & 8.340 & 23.97 & 38.89 \\
\hline & 3 & 7.25 & 2.955 & 3.41 & 11.12 \\
\hline & 4 & 5.38 & - & 5.38 & 5.38 \\
\hline \multirow[t]{4}{*}{ Atheists (\%) } & 1 & 1.25 & 0.978 & 0.16 & 2.79 \\
\hline & 2 & 4.99 & 0.376 & 4.66 & 5.40 \\
\hline & 3 & 2.02 & 1.613 & 0.27 & 4.41 \\
\hline & 4 & 1.40 & - & 1.40 & 1.40 \\
\hline
\end{tabular}


It can be noticed that, among the four clusters, clusters 2 and 3 have the highest average values for all the characteristics regarding labor market and female labor force.

The profile of cluster 2 (Czech Republic, Estonia, and Latvia) shows that these countries have a good performance of the indicators that influence female labor force participation. These indicators refer to both labor market characteristics (Labor market efficiency, GDP per capita, Intensity of local competition, and Total tax rate) and to female labor force characteristics (Share of women employed in the non-agricultural sector). Cluster 2 is also characterized by a greater within cluster heterogeneity according to Share of women employed in the non-agricultural sector compared to other clusters.

Cluster 3 (Hungary, Lithuania, Poland, Russia, Slovakia, and Slovenia) is characterized by the highest level of Female tertiary education enrollment rate $(70.65 \%)$, and also by a higher within cluster heterogeneity according to this characteristic, comparing to the others cluster.

Countries that belong to cluster 1 (Bulgaria, Croatia, Montenegro, Romania, and Serbia) lag behind the countries grouped in clusters 2 and 3 with respect to the determinant factors of female labor force participation. Regarding the average value of GDP per capita for cluster 1, it can be seen that it is almost half the value for clusters 2 or 3. Most of the countries in cluster 1 (Romania, Bulgaria, Montenegro, and Serbia) have values of GDP per capita inferior to 10,000 USD (Serbia has the lowest level equal to 5,907 USD), the only exception being Croatia with GDP per capita around 13,500 USD). Within this cluster, Bulgaria has the highest value for the variable Share of women employed in the non-agricultural sector.

Comparing to the first three clusters, Macedonia (cluster 4) has the lowest levels for almost all the variables, excepting Intensity of local competition.

Among the four clusters, clusters 1 and 3 have the highest percentages of Christian population $(86.35 \%$ in cluster 1 and $88.05 \%$ in cluster 3 ), while cluster 4 (Macedonia) has the highest percentage of Muslims (28.97\%).Moreover, cluster 2 has the highest percentage of Agnostics (29.27\%) as compared to the other clusters. Actually, Czech Republic registers the highest percentage of Agnostic population (38.89\%) among the 15 countries in the study.

The variation of the determinant factors of labor force participation among countries may explain the differences in female participation by clusters.

\section{Differences in female labor force participation by clusters of countries in Central and Eastern Europe}

We have tested the differences in the means of each variable among the four clusters using ANOVA method and multiple comparisons tests. The differences among the four clusters are tested with F test, while for pairwise comparisons we used the StudentNewman-Keuls statistic.

The profile of clusters according to Female labor force participation rate highlights the highest average female labor force participation rate $(53.66 \%)$ for cluster 2 (Czech Republic, Estonia, and Latvia). The highest within cluster variation according to this variable is obtained for cluster 3. In this cluster, Russia and Lithuania have the highest participation rates of women on the labor market (57\% and 56\%, respectively) while Hungary has a much lower value (45\%), (Table 3). In cluster 1, female labor participation rate varies from $49 \%$ in Romania to $43 \%$ in Montenegro. 
THE STATISTICAL ANALYSIS OF LABOR MARKET AND FEMALE LABOR FORCE CHARACTERISTICS IN CENTRAL AND EASTERN EUROPEAN COUNTRIES

Table 3 The clusters' profile according to female labor force participation rate

\begin{tabular}{|c|c|c|c|c|}
\hline Cluster & Mean & Std. Deviation & Minimum & Maximum \\
\hline 1 & 45.80 & 2.588 & 43.00 & 49.00 \\
\hline 2 & 53.66 & 3.214 & 50.00 & 56.00 \\
\hline 3 & 51.66 & 4.457 & 45.00 & 57.00 \\
\hline 4 & 43.00 & - & 43.00 & 43.00 \\
\hline \multicolumn{5}{|c}{ Source: Authors' tabulation in SPSS 20.0 } \\
\hline
\end{tabular}

The assumption regarding the homogeneity of variances was met (the Levene's test-has a significance level higher than 0.05) and therefore the ANOVA results are presented in Table 4.

Table 4 The ANOVA results for female labor force participation rate (\%)

\begin{tabular}{|c|c|c|c|c|c|}
\hline & $\begin{array}{c}\text { Sum of } \\
\text { Squares }\end{array}$ & Df & Mean Square & F & Sig. \\
\hline Between Groups & 190.933 & 3 & 63.644 & 4.769 & .023 \\
\hline Within Groups & 146.800 & 11 & 13.345 & & \\
\hline Total & 337.733 & 14 & & & \\
\hline
\end{tabular}

Source: Authors' tabulation in SPSS 20.0

The differences in female labor force participation rate among the four clusters are significant at a level associated to ANOVA F test lower than 0.01 .

In order to identify the differences for all possible pairs of clusters we apply the posthoc multiple comparisons procedure. Because cluster 4 is composed of only one country, this cluster is excluded from the multiple comparisons procedure.

Based on the results obtained for the Student-Newman Keulstest (Table 5) and on the box-plot (Figure 2), we notice that there are significant differences between the clusters according to female labor force participation rate. Moreover, we can see that these differences are more evident between cluster 1 and the other two clusters.

Table 5 The results of Student-Newman-Keuls pairwise comparisons test

\begin{tabular}{|c|c|c|c|}
\hline \multicolumn{4}{|c|}{ Female labor force participation rate } \\
\hline Cluster & $\mathrm{N}$ & Subset for alpha $=0.05$ \\
\cline { 2 - 4 } & & 1 & 2 \\
\hline 1 & 5 & 45.8000 & 51.6667 \\
\hline 3 & 6 & & 53.6667 \\
\hline 2 & 3 & 1.000 & .440 \\
\hline Sig. & & & \\
\hline Means for groups in homogeneous subsets are displayed. \\
\hline \multicolumn{4}{|c|}{$\begin{array}{l}\text { a. Uses Harmonic Mean Sample Size = 4.286. } \\
\text { b. The group sizes are unequal. The harmonic mean of the } \\
\text { group sizes is used. Type I error levels are not guaranteed. }\end{array}$} \\
\hline \multicolumn{3}{|c|}{ Source: Authors' tabulation in SPSS 20.0 }
\end{tabular}


Clusters 2 and 3 that are characterized by a good performance of the indicators concerning labor market and female labor force characteristics show also the highest level of female labor force participation.

Furthermore, the association of religion to the clusters shows that religion has shaped differently the female labor force participation. It can be seen that cluster 2 (formed of countries with a high percentage of Agnostics and Atheists) has important participation rates of female population. These results are consistent with the ones published by Pastore and Tenaglia (2013).

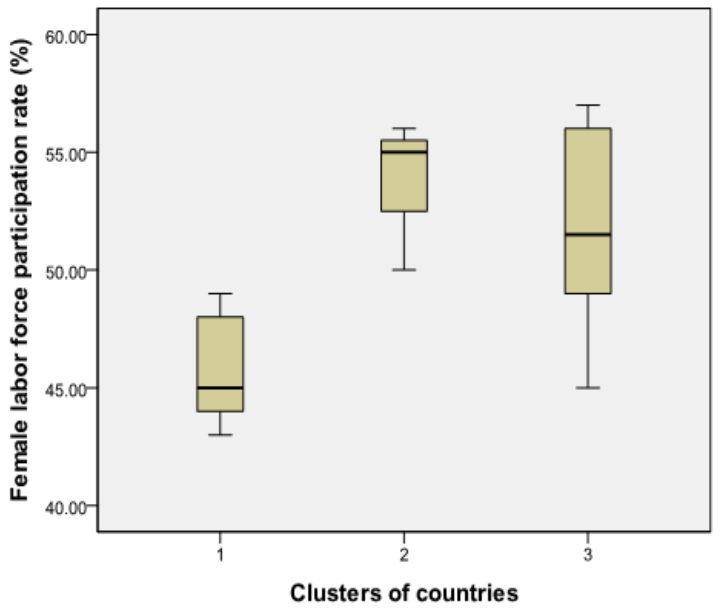

Figure 2 The distribution of female labor force participation rate by clusters of countries

Source: Authors' tabulation in SPSS 20.0

The positive relationship between female labor force participation and GDP per capita is represented graphically by clusters of countries in the scatter plot (Figure 3). The clusters 1 and 4 are characterized by lower GDP per capita and female participation rate levels compared to clusters 2 and 3 .

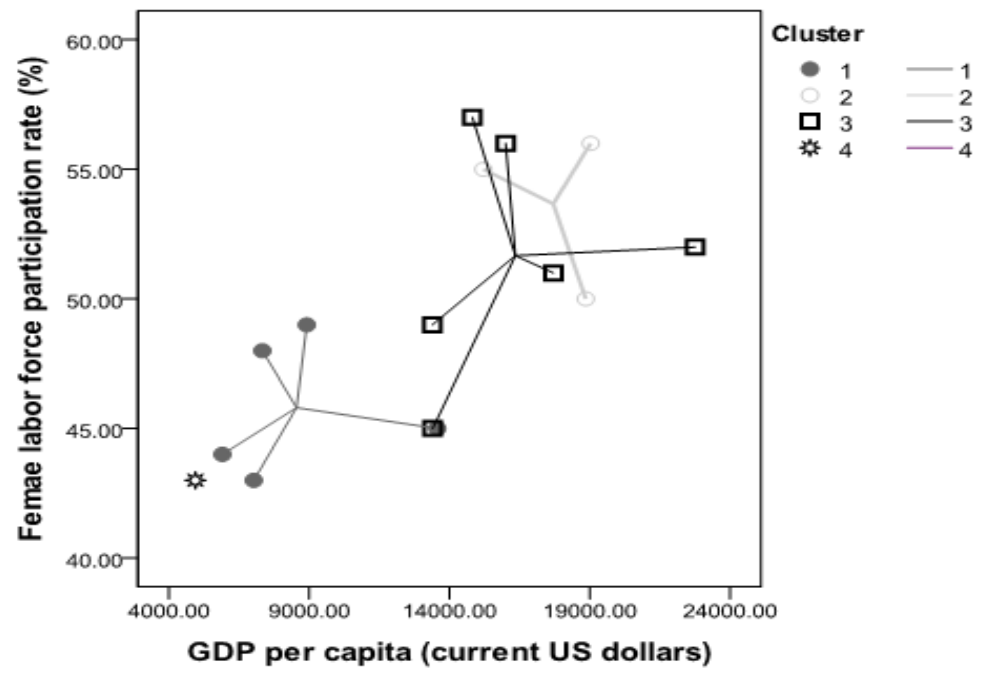

Figure 3 The distribution of Central and Eastern European countries, by clusters, according to GDP per capita and female labor force participation rate Source: Authors' tabulation in SPSS 20.0 
Macedonia (cluster 4) is characterized by low values on both variables, GDP per capita and female force participation rate. On the opposite side, cluster 2 has the highest mean values (centroids) both for female participation rate and GDP per capita. In cluster 3, Slovenia, the country with the highest level of GDP per capita (22,756 USD) is opposed to Hungary, the country with the lowest level of GDP per capita in cluster $2(13,405$ USD).

\section{Conclusions}

In this paper we aimed to analyze the characteristics of labor markets and female labor force in countries from Central and Eastern Europe in order to identify differences in female labor force participation rate.

To this purpose, we have first selected the characteristics of female labor force and labor market that are highly correlated with female labor force participation rate. In the second step, considering the variables that characterize both female labor force and the labor market, we have identified four groups of countries. Finally, we emphasized the disparities among the four clusters according to female labor force participation.

The results show, despite the fact that Central and Eastern European countries had a common body-the socialist policy regarding female employment, the transition period outlined a different female labor market, with specific characteristics of female labor force.

We identified clusters of countries with a similar profile of female labor force characteristics that explain the variation in female labor force participation.

Czech Republic, Estonia, and Latvia belong to the same cluster that is defined by the highest average level of female participation rate and of the indicators describing labor market and female labor force characteristics. In addition, the high participation rate of women on labor market in these countries is associated with high percentage of Agnostic population.

Macedonia and other countries, such as Hungary, Lithuania, Poland, Russia, Slovakia, and Slovenia, have lower participation rates of female population due to the reduced performance of their labor markets.

The results of this study would motivate the necessity of creating similar policies that would allow the efficient utilization of a potential important resource and would increase the individuals' quality of life.

\section{References}

Aboohamidi, A. \& Chidmi B. (2013), Female Labor Force Participation in Pakistan and Some MENA Countries, Selected paper prepared for presentation at the Southern Agricultural Economics Association Annual Meeting, http://ageconsearch.umn.edu/bitstream/143097/2/SAEAAboohmaidi_Chidmi .pdf, 1-19.

Anker, R. (1998), Gender and Jobs: Sex Segregation of Occupations in the World, Geneva, International Labor Office.

Brăilean, T. (2014), Blissful, New Delhi, Sanbun Publishers.

Cattinelli, I., Valentini, G., Paulesu, E., Borghese, A. (2013), A Novel Approach to the Problem of Non-uniqueness of the Solution in Hierarchical Clustering, IEEE Transactions on Neural Networks and Learning Systems, 24(7), 1166 - 1173.

Cazes, S. (2002), Do Labor Market Institutions Matter in Transition Economies? An Analysis of Labor Market Flexibility in the Late Nineties, ILO Discussion Paper 140, 1 - 29. 
Cipollone, A., Patacchini, E., Vallanti, G. (2013), Women Labor Market Participation in Europe: Novel Evidence on Trends and Shaping Factors, IZA Discussion Paper No. 7710, 1 - 50.

Cloin, M., Keuzenkamp, S., Plantenga, J. (2011), A Matter of Culture and Cost? A Comparison of the Employment Decisions made by Mothers. Work, Employment and Society 25 (3), 468 - 486.

Cuberes, D., Teignier, M. (2012). Gender Gaps in the Labor Market and Aggregate Productivity, Sheffield Economic Research Paper SERP 2012017, 1 - 33.

DeAnne, A., Hoteit, L., Rupp, C., Sabbagh, K. (2012), Empowering the Third Billion. Women and the World of Work in 2012, Booz and Company.

Diaz Garcia, M. C., Welter, F. (2011), Gender Identities and Practices: Interpreting Women Entrepreneurs' Narratives, International Small Business Journal, $1(21), 1-21$.

DiCecio, R., Engemann, K. M., Owyang, M. T., Wheeler, C. H. (2008), Changing Trends in the Labor Force: A Survey, Federal Reserve Bank of St. Louis Review, 90(1), 47 - 62.

Dollar, D., R. Gatti (1999), Gender Inequality, Income, and Growth. Are Good Times Good for Women?, World Bank Gender and Development Working Paper No. 1 (Washington), 1 - 40.

Elborgh-Woytek, K., Newiak, M., Kochhar, K., Fabrizio, S., Kpodar, K., Wingender, P., Clements, B., Schwartz, G. (2013). Women, Work, and the Economy: Macroeconomic Gains From Gender Equity, International Monetary Fund Staff Discussion Note, 1 - 32.

European Commission (2011), Labor Market Developments in Europe, DirectorateGeneral for Economic and Financial Affaire, Statistical Books, Luxembourg.

Gutierrez-Domenech, M., Bell, B. (2004), Female Labor Force Participation in the United Kingdom: Evolving Characteristics or Changing Behaviour?, Bank of England Working Paper 221.

Heinegg, A., Melzig, R., Sprout, R. (2007), Labor Markets in Eastern Europe and Eurasia, Working Paper Series on the Transition Countries No. 6, Bureau for Europe \& Eurasia, U.S. Agency for International Development, 1 -79.

Inglehart, R., Baker, I. (2000). Modernization, Cultural Change, and the Persistence of Traditional Values, American Sociological Review 65(1), 19 - 51.

Jaba, E. (1979), Female Labor Force - Iasi Region. Social Statistics Research, Iași, Alexandru Ioan Cuza University Publishing House.

Jaba, E., Balan, C.B., Roman, M., Roman, M. (2010), Statistical Evaluation of Spatial Concentration of Unemployment by Gender. Economic Computation and Economic Cybernetics Studies and Research, 44(3), 79 - 91.

Jaumotte, F. (2003), Female Labor Force Participation: Past Trends and Main Determinants in OECD Countries, OECD Economics Department Working Papers, No. 376, 1 - 64.

Karshenas, M. (1997), Economic Liberalization, Competitiveness and Women's Employment in the Middle East and North Africa, Department of Economics SOAS, University of London, 1 - 40.

Loko, B., Diouf, M.A. (2009), Revisiting the Determinants of Productivity Growth: What's New?, IMF Working Paper 09/225, 1 - 29.

McDaniel, A. (2014), Women's Rising Share of Tertiary Enrollment: A Cross-National Analysis. FIRE: Forum for International Research in Education, 1(2), 1 - 21.

Noback, I., Broersma, L., Van Dijk, J. (2013), Gender-Specific Spatial Interactions on Dutch Regional Labor Markets and the Gender Employment Gap, Regional Studies, 47(8), 1299 - 1312.

Norton, S. W., Tomal, A. (2009), Religion and Female Educational Attainment, Journal of Money, Credit and Banking, 41(5), 961 - 986. 
Norusis, M. (2011), IBM SPSS Statistics 19 Guide to Data Analysis, Inc. SPSS.

OECD (2009), OECD Employment Outlook 2009: Tackling the Jobs Crisis, available at http://www.oecd.org/employment/emp/43687710.pdf, 1 - 7.

Paci, P., Reilly, B. (2004), Does Economic Liberalisation Reduce Gender Inequality in the Labour Market? The Experience of the Transitional Economies of Europe and Central Asia, World Bank, Washington D.C.

Palaşcă, S., Enea, S., Jaba, E., Roman, M. (2014), Measuring Globalization by means of Business Cycles Synchronization. A Fuzzy Cluster Framework, Economic Computation and Economic Cybernetics Studies and Research, 48(3), 39 - 57.

Pastore, F., Tenaglia, S. (2013). Ora et non Labora? A Test of the Impact of Religion on Female Labor Supply, IZA Discussion Paper No. 7356, 1 - 39.

Pastore, F., Verashchagina, A. (2008), The Determinants of Female Labour Supply in Belarus, Institute for the Study of Labor Discussion Paper No. 3457, 1 - 24.

Sands, D. (2013), The Changing Labor Market: Delivering for Women, Delivering for Growth, available at http://www.voced.edu.au/content/ngv\%3A72794, 1 - 56.

Tan, P.N., Steinbach, M., Kumar, V. (2006), Introduction to Data Mining, New York, Pearson Education.

Tryfos, P. (1998), Methods for Business Analysis and Forecasting: Text \& Cases, New York, Wiley.

Wilton, N. (2013), An Introduction to Human Resource Management. $2^{\text {nd }}$ Edition, Los Angeles, SAGE Publications Ltd. 